\title{
Purpose in life and work-related stress in mariners. Mediating role of quality of marriage bonds and perceived anxiety
}

\author{
Aleksandra Peplińska ${ }^{1}$, Maria Jeżewska ${ }^{2}$, Irena Leszczyńska ${ }^{2}$, Piotr Połomski ${ }^{1}$ \\ ${ }^{1}$ Institute of Psychology, University of Gdansk, Poland \\ ${ }^{2}$ Institute of Maritime and Tropical Medicine, Medical University of Gdansk, Poland
}

\begin{abstract}
Background: The specific character of mariners' work is connected with many factors conducive to stress, overload, fatigue and emotional tension, all of which can negatively influence subjective quality of life, including particularly the sense of life's purpose and meaning. However, over the course of entire life one plays many various roles and takes part in many areas of life which influence one another, both positively and negatively. Undoubtedly one of such areas, essential from the point of fulfilling individual's important needs, is one's family and marriage that can function as a crucial factor for neutralising on-the-job problems and tensions.

Aim: The research presented here attempts to verify the relation between stress perceived by mariners and their sense of purpose in life along with the mediating role of marriage quality and anxiety levels.

Materials and methods: $A$ total of 210 mariners working on deep-sea ships were examined. The following research tools were applied in the study: the Purpose in Life Test (PIL), the State-Trait Anxiety Inventory (STAl), the Perceived Stress Questionnaire (PSQ) and the Questionnaire of Suitable Marriage (KDM).

Results and conclusions: The results arrived at indicate that both marriage satisfaction and anxiety levels can indeed mediate the relation between stress and sense of purpose in life among mariners.
\end{abstract}

(Int Marit Health 2014; 64, 2: 87-92)

Key words: work-related stress, quality of life, marital satisfaction, purpose in life

\section{INTRODUCTION}

In the modern era of changes and transformations in the job market, stress - by determining the consequences in the area of subjective sense of purpose in life - is beginning to constitute the immanent trademark of the $21^{\text {st }}$ century [1]. Many careers and jobs cause overload or fatigue, thus they are conducive to significant health and psychological after-effects and can consequently influence negatively the evaluation of one's quality of life [2]. Due to the specific character of work performed on deep-sea ships, the job of a mariner is to be ranked among such careers [3]. The analysis of the literature on the subject allows singling out many properties resulting from the specific character of working in such an insular environment as a ship [4]. Among those most often mentioned are: the risk of health or life loss [5], deprivation of a number of essential needs resulting from a long-term separation from one's beloved [3,5], social threats associated with the tension of prolonged staying in a closed group of people (possible interpersonal conflicts included) [6], restricting the freedom of movement, and minimising the sphere of privacy [3]. Moreover the following factors are also indicated: discomfort associated with onerous physical working conditions (swaying, vibrations, noise, climate and time zone changes), psychological and physical overload associated with working in demanding weather conditions [7], e.g. during storms, or frustrating

Dr Maria Jeżewska, Clinic of Occupational and Internal Diseases, Institute of Maritime and Tropical Medicine, Medical University of Gdansk

ul. Powstania Styczniowego 9B, 81-519 Gdynia, Poland, tel: +48 5834919 32, e-mail: mariajez@gumed.edu.pl 
situations resulting from faulty job organisation on ship and/ /or in port. Because these factors occur in large number, are long in duration and chronic, they determine - as proven by research conducted in this field - the sense of permanent emotional stress experienced by the majority of mariners, and it tends to increase the longer a cruise continues $[4,8]$. An essential determinant of this tension is by far the situation of long-term sea isolation [9], which according to Korczyński [10] is a specific type of extremely difficult situation connected with more or less long-term disruption of one's optimal levels of stimulation $[11,12]$. The additional factor which is particularly tied to this already uncomfortable and difficult to bear situation, is the separation from one's family, which is often reported by mariners as the most vexing stress-causing stimulus $[3,8]$. As previously mentioned, subjectively perceived and experienced stress is frequently the cause of lowering one's general psychological well-being and hence can influence the subjective assessment of life quality to drop, later affecting other areas of actions and functioning [13]. It seems that working as a deep-sea mariner particularly contributes to such consequences [3].

The notion of life quality has been evolving over the years [13]. At first it was only associated with possessions or adequate living standards, however, as time passed and more studies on this subject were carried out, it broadened to include non-material values - mainly happiness, freedom or health [14]. In our times, quality of life is viewed as a theoretical construct, investigated in its social context, and referring to an individual's subjective expectations about some chosen areas of his or her life, the degree of fulfilling needs and achieved goals [14]. In contemporary literature of broadly defined quality of life two concepts are brought to light - life satisfaction and the feeling of happiness [3]. The first one is comprehended as a degree to which an individual assesses positively quality of one's life as a whole, and one of the elements of this global satisfaction are marital relationships $[3,14]$. The feeling of happiness as formulated by Czapiński [15] is still a broader meaning of this satisfaction and consists of three interrelated layers - the will to live, a positive attitude towards life as a whole, and partial satisfactions which are made up of evaluations of individual areas of life, including professional life and marriage. What is inevitably connected with the quality of life is a sense of its purpose; it sets the ground for discussion presented in this article, and its integrity can be treated as an indicator of an individual's mental health [16]. The findings show $[14,17]$, that persons satisfied with their own life and its individual areas (among them: an intimate relationship with a chosen partner) are able to set clear and realistic life goals, be happy about their own achievements, and deal more effectively with the hassles of everyday life. According to Popielski [18], the structure of a sense of purpose in life is built up of four components: intellectual, emotional, volitional/aspirational and existential/active. The first one, by referring to understanding the nature of human life, one's environment and personal goals, determines the capacity to know oneself, the history of one's life, social relations and surroundings. The second component is closely tied with man's individual abilities to experience himself and respond to values, including achievements and failures, aspirations and successes. The third one takes into account human competence to make choices and adopt attitudes, while the last one is formulated as a cause of realising one's purpose in life and the effect of its existence. The sense of life's purpose, in the author's opinion $[3,18]$, is associated directly with personal experiences of an individual, determined by his or her personality, goals and aspirations, and is characterised by individualised development and considerable stability.

Studies on the subject of purpose in life among mariners show that, compared with their wives, they score significantly lower on the general meaning of life [3], in particular on the sense of life affirmation, responsibility and freedom, and significantly more often than their partners report having suicidal thoughts. They do demonstrate, however, a rather high level of life goals [3]. Similar results were obtained in comparative analyses of mariners and men performing jobs in which separation is not an issue and working conditions are less stressful. It is therefore reasonable to conclude that the measured and declared sense of purpose in life is significantly lower among mariners. There may be many reasons for this phenomenon, but the majority of them come down to the specific character of mariners' work and life [4]. Moreover, the findings of these research studies suggest that the mentioned low sense of life meaning is related to perceived stress levels, and, in turn, one essential predictor of high sense of life meaning among mariners was their style of coping with stress, particularly the task-oriented one; it helps to lower perceived stress levels and allows to take constructive actions in the face of adversities [3].

As such, the stress resulting from the specific character of this work and its environment can noticeably and negatively influence the general sense of the whole life's purpose. What is more, this influence is not isolated from other areas of one's functioning.

In the modern world various areas of our life interpenetrate more and more often, thus influencing our view of what our life quality is like in general [13]. These penetrations can be negative in character, adding new sources of stress, as well as positive, forming a kind of a buffer against many sacrifices. Quality of marital bonds can serve as such a buffer, it is not impossible, however, for it to function as a generator of stress. Studies of the subject carried out among many mariners indicate that subjectively assessed 
marriage quality clearly and significantly mediates forming the relation between anxiety and perceived occupational stress [19]. It can partly moderate that relation, or in case of unsatisfactory marital bonds - intensify it significantly.

The authors wish to present an attempt at continuing the studies mentioned above, that deal with analysing the link between stress related to performing such a difficult and mentally burdening job as the one of mariners and perceived anxiety levels, as well as the mediatory role of marital quality, with the extension of broadly defined sense of purpose in life among deep-sea mariners. It was attempted to find whether (and - if so - to what extent) the quality of marriage and perceived anxiety can mediate the relation between sense of purpose in life and subjectively perceived stress in mariners. Taking into account the previous findings and current knowledge, both these factors (i.e. marriage quality and perceived anxiety) were expected to function as significant mediating variables (mediators) in the relation between perceived stress and subjective sense of purpose in life.

\section{MATERIALS AND METHODS}

The research was conducted over the course of two years (2011-2012), and a total of 210 mariners working on deep-sea ships were subjected to it. The majority of examined participants lived in the area of northern Poland, their age varied between 25 and 60 years and their marriages had been lasting from 1 to 35 years. The majority of participants had a secondary education (57.3\%), 32.5\% (mainly those in the officer corps) continued with higher education, and $10.2 \%$ had a vocational education. Four diagnostic tools were used in the study: the Purpose in Life Test (PIL) created by Crumbaugh and Maholick, and adapted by Płużek [18], which allows to measure both a general sense of purpose in life as well as its various aspects: the sense of life's goal and meaning, affirmation of life, the evaluation of oneself and one's life, the amount of responsibility and freedom, and attitudes towards suicide and death; the State-Trait Anxiety Inventory (STAI) created by Spielberger [20], which embraces two self-assessment scales intended for measuring two types of anxiety - as a current state and as a relatively stable disposition to experience fits of anxiety and fear (in this study only the former factor was used, i.e. anxiety understood as a fluid emotional state of an individual, subjectively characterised by experiencing tension and anxiety, coupled with the increased activity of the autonomous nervous system) [20]; the Perceived Stress Questionnaire (PSQ) created by Levenstein and adapted into Polish by Plopa [16], which - apart from a general level of perceived stress - can measure its intensity in subscales of fatigue, irritability, worrying, psychical strain, lacking the joy of life, experiencing external pressures and overload [3]; and the Questionnaire of
Suitable Marriage (KDM) by Rostowski [21], which allowed to measure general marriage satisfaction as well as levels of experienced love and happiness, emotional bonds with one's partner, intimacy, similarities in behaviour, sexual gratification and having children.

In order to conduct statistical analyses of the data gathered, structural equation modelling (SEM) was employed, as calculated with Amos 21.

\section{RESULTS}

In the model presented in Figure 1 it was assumed that for mariners both the level of marriage satisfaction and perceived job-related anxiety acted as mediating variables in the relation between occupational stress and reported sense of purpose in life. Moreover, in the context of earlier findings [19] it was postulated in this set of variables that the "regulatory" role in the relation "occupational stress and sense of purpose in life among mariners" resides mainly in marital relationships ("close" mediating variable - proximal mediator), which influence and at the same time regulate if and how one reacts with fear ("distant" mediating variable - distal mediator) when faced with mariners' occupational stress.

Results of conducted analyses (Table 1) prove that the model fits the data acceptably well and is interpretable.

In order to estimate the mediating role of marriage satisfaction and state-anxiety in forming the relation between stress and reported sense of purpose in life among mariners, an analysis testing the significance of direct and indirect effects was carried out by applying a bootstrap simulation of 1,000 trials. The following Table 2 shows the result of that analysis.

As demonstrated in Figure 1 above, direct effect of job-related stress in mariners on their reported purpose in life is statistically significant, moderate and negative $(b=-0.147, p=0.01)$. The influence described and the significance of job-related stress is further intensified considerably (indirect effect, $b=-0.204, p=0.00$ ) in the context of how the participants evaluate their marital relationships and what the levels of reported job-induced anxiety are. Because the total effect and the influence of stress on purpose in life (mediated by marital satisfaction and job-related stress in examined mariners) remains significant $(b=-0.351$, $p=0.01$ ), it seems justified to conclude that these two variables - marriage satisfaction levels and job-induced state-anxiety - partially mediate the relation between job-related stress and reported sense of purpose in life. On the basis of conducted analyses it was also found that the level of marriage relation quality is a partial but significant mediator that counteracts relations of stress and reduces reactions of fear in participants (direct effect: $b=0.286$, $p=0.00$, indirect effect: $b=0.124, p=0.01$ ) and also 


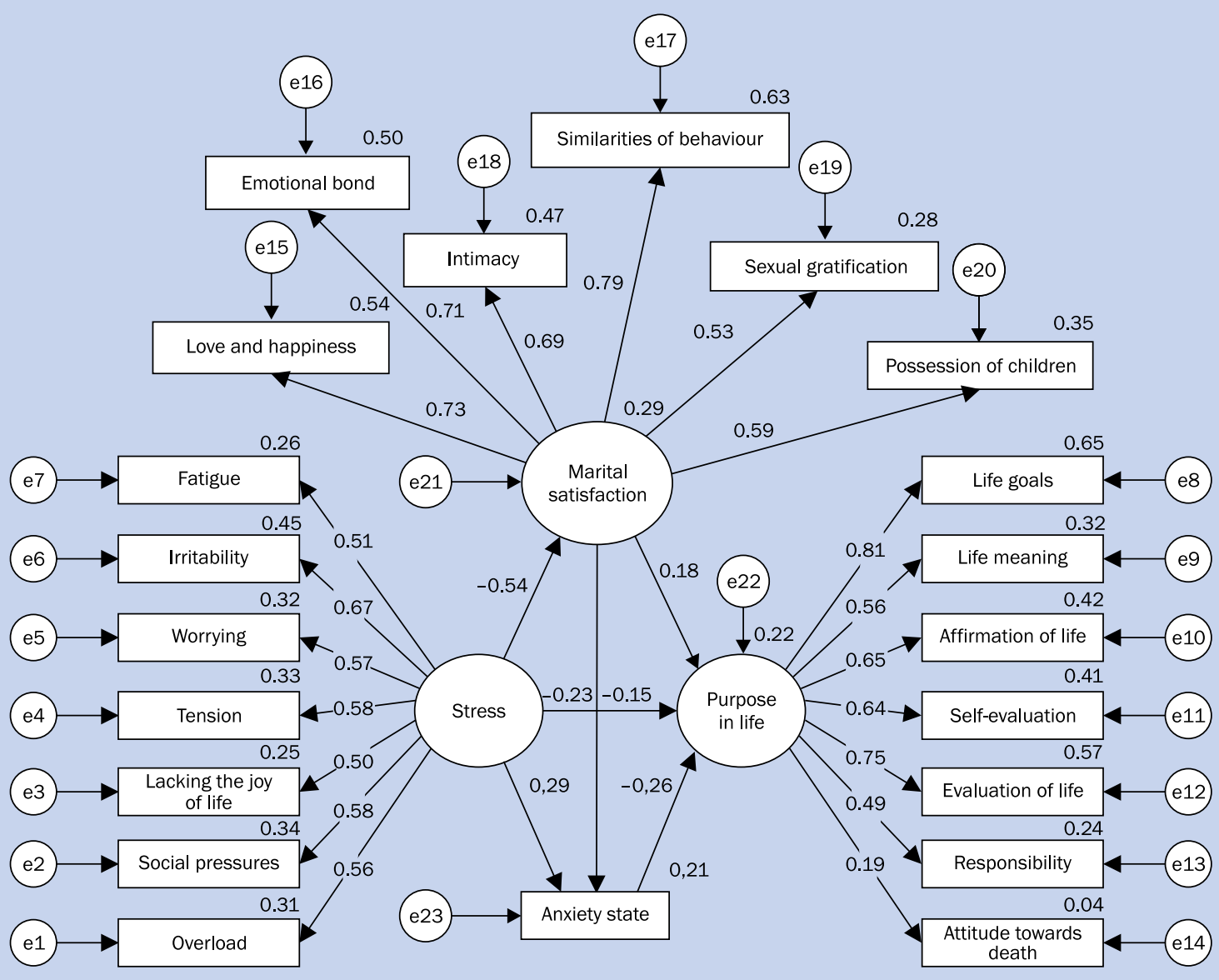

Figure 1. Path diagram presenting the results for the approximated model

Table 1. Indicators of global model fitting

\begin{tabular}{lllll}
\hline & CFI & RMSEA & GFI & AGFI \\
\hline$\chi^{2}(184)=215.275 ; p=0.057$ & 0.902 & 0.029 & 0.942 & 0.891
\end{tabular}

CFI - comparative fit index; RMSEA - root mean square error of approximation; GFI - goodness of fit index; AGFI - adjusted goodness of fit index

Table 2. Stress and sense of purpose in life - mediating role of marriage satisfaction and state-anxiety

\begin{tabular}{llll} 
& \multicolumn{2}{l}{ Purpose in Life (PIL) } & \\
\cline { 2 - 4 } & Indirect effect & Direct effect & Total effect \\
\hline Stress (PSQ) & $-0.204^{\star}$ & $-0.147^{*}$ & $-0.351^{*}$ \\
Lower boundary & -0.339 & -0.379 & -0.522 \\
Higher boundary & 0.092 & 0.093 & -0.167
\end{tabular}

${ }^{*} \mathrm{p}<0.001$; PSQ - Perceived Stress Questionnaire

that state-anxiety mediates (partially weakening the positive link) the relation between evaluating one's marriage and the sense of purpose in life (direct effect: $b=0.18$, $p=0.01$, indirect effect: $b=0.061, p=0.03$ ). The above gives ground to the conclusion that marital relationships (as a proximal mediator) when related to anxiety (as a distal mediator which depends on the proximal one and results from perceived stress and quality of marriage relationship) plays a direct role in the relation between stress and sense of purpose in life. 


\section{DISCUSSION}

A general sense of one's purpose in life is significantly determined by the levels of satisfactions from individual, but interrelated, areas of one's life [13]. Undoubtedly job career and personal/family life are two basic scopes of human activity, in which important needs are fulfilled, goals are achieved and life priorities are set $[2,13]$. Between these areas occurs a never-ending flow, either positive or negative, which determines specific and subjective quality of life. Over the past years the subject of influences described above has been very often probed in numerous scientific studies [1, 13, 22], but relatively few of them concern the occupational category of mariners. From those that can be found in the literature of the subject, one can conclude that, on the one hand, positive connections exist between life satisfaction and general quality of life, particularly in the aspect of social relations, but on the other - negative links between the mentioned subjective evaluation of life quality, perceived stress and a sense of psychological workload are there as well [23]. The results of analyses presented above closely correspond to the results obtained in research carried out earlier: negative relations were observed between marital life satisfaction and stress perceived by mariners, and positive relations between stress and state-anxiety [19]. In an attempt to go one step further, authors of the present study tried to verify in what way these patterns influence a general sense of purpose in life among mariners. On the basis of conducted analyses it can be stated that a negative relation exists between stress perceived by mariners and their reported subjective sense of purpose in life. Experiencing role overload, fatigue, high levels of emotional tension, and external pressures lead to gradual and specific drainage of one's remedial resources, thus negatively influencing the general psychological well-being of an individual and his or her joy of life [1]. Other areas of mariners' functioning (e.g. family, intimate relationships) could act as a neutralising buffer against these dependencies, by aiding a kind of regeneration of one's remedial resources, by compensating for what has to be sacrificed for one's professional life, or by providing valuable emotional resources [22]. So intimate relationships and satisfying emotional bonds within a family could neutralise the negative effect that perceived stress has on a general sense of purpose in life: a relation of this kind can be observed in the obtained findings. Quality of marital life is, in the opinion of mariners, a significant mediator of the link between perceived stress and reported sense of purpose in life. However, the condition necessary for this link to have its neutralising effect is a high and satisfying level of quality of marriage life. But the examinations concerning the quality of mariners' marriages show that it is rather wives of marines, in comparison with their partners, who demonstrate higher levels of marital satisfaction [3]. It is therefore possible to conclude that reported levels of satisfaction from their marriages are not high among mariners. On the other hand, the examination presented here showed that marital satisfaction is also an essential mediator of the positive link between perceived stress and anxiety, which could neutralise this relation. This result closely corresponds to the findings quoted earlier [19]. However, the lack of marital satisfaction may intensify the poignancy of stress, increase the probability of experiencing fear and thus negatively influence a general sense of purpose in life. Analyses conducted on this point show that marriage quality, through influencing levels of anxiety experienced by mariners, acts as a significant mediator in forming a sense of meaning concerning mariners' own actions (including, probably, the fact of performing such a difficult job) as well as their entire life. As demonstrated by the presented model and relevant analyses, a situation particularly disturbing for the sense of purpose in life among the participants may happen when job-related stress, after all of considerable proportions, comes up against bad marital relations, which in turn generate additional intense anxiety and fear, further lowering the level of reported sense of meaning concerning one's actions in life.

\section{CONCLUSIONS}

A twofold kind of spillover can occur between various individual areas of one's functioning - of either positive or negative character. In the case of negative spillover problems and stress generated in one area are transmitted to the second area, its problems, strains and conflicts. In the process they determine a lower level of subjective purpose in life. However, a high level of satisfaction from one of the areas of functioning can provide a neutralising factor to the problems experienced in another area. It eliminates their negative influence on a general psychological well-being of an individual and, in a specific way, protects a subjective sense of life quality, particularly a sense of purpose in life. The study conducted on a group of mariners indicated that threats connected with the practiced profession and determining a high level of perceived stress are in relation with a low level of satisfaction from one's marital life and thereby with a perceived high level of anxiety, which in turn can lead to lowering a sense of purpose in life among mariners.

\section{REFERENCES}

1. Poelmans S, Stepanova O, Maruda A. Positive spillover between personal and professional life: definitions, antecedents, consequences and strategies. In: Korabik JK, Lera DS, Whitehead DL eds. Handbook of Work. Family Integration. Research, theory and best practices. Elsevier, San Diego, CA 2008: 141-156.

2. Peplińska A. Psychologiczne i zdrowotne konsekwencje równoważenia ról zawodowych i rodzinnych. In: Rostowska T, Budziński W eds. Zawodowe i zdrowotne problemy człowieka w różnych 
okresach dorosłości. Wydawnictwo Adam Marszałek, Toruń 2012: 64-85.

3. Peplińska A. Małżeństwo a specyfika pracy marynarzy - perspektywa psychologiczna. Oficyna Wydawnicza Impuls, Kraków 2011.

4. Jeżewska M, Iverson R. Stress and fatigue at sea versus quality of life. Int Marit Health 2012; 63: 106-115.

5. Leka S. Psychosocial hazards and seafarers health: priorities for research and practise. Int Marit Health 2004; 55: 137-154.

6. Borucki Z. Stres i przystosowanie w zawodzie marynarza. Przegl Psychologiczny 1972; 2: 63-74.

7. Leszczyńska I, Jeżewska M. Psychosocial burden among offshore drilling platform employees. Int Marit Health 2010; 61: 159-157.

8. Plopa M. Stres w izolacji morskiej - psychospołeczne uwarunkowania. Wyd. UG, Gdańsk 1996.

9. Carotenuto A, Molino I, Fasanaro AM, Amenta F. Psychological stress in seafarers: a review. Int Marit Health 2012; 63: 188-194.

10. Korczyński W. Psychofizyczna istota sytuacji izolacji morskiej. In: Psychofizyczne uwarunkowanie skuteczności działań na morzu. I Konferencja Naukowa, Gdynia: AMW, Pracownia Psychologiczna Marynarki Wojennej, 1988: 83-102.

11. Jeżewska M, Leszczyńska I, Jeremin B. Work-related stress at sea self estimation by maritime students and officers. Int Marit Health 2006; 57: 66-75.

12. Leszczyńska I, Jeżewska M, Jeremin B. Work-related stress at sea. Possibilities of research and measures of stress. Int Marit Health, 2007; 58: 93-102.
13. Peplińska A, Rostowska T. Quality of life and relations between work and family. Acta Neuropsychologica 2013; 11: 77-92.

14. Rostowska T. Małżeństwo, rodzina, praca a jakość życia. Oficyna Wydawnicza Impuls, Kraków 2008.

15. Czapiński J. Psychologia szczęścia: przegląd badań i zarys teorii cebulowej. Pracownia Testów Psychologicznych PTP, Warszawa 1994.

16. Plopa M. Psychologia rodziny. Teoria i badania. Wydawnictwo EUH-E, Elbląg 2005.

17. Rook K, Dooley D, Catalano R. Stress transmission: the effects of husbands' job stressors on the emotional health of their wives. J Marriage Family 1991; 53: 165-177.

18. Popielski Z. Fenomen religijności człowieka a noetyczny wymiar egzystencji. Zeszyty Naukowe KUL 1998; 3-4.

19. Peplińska A, Jeżewska M, Leszczyńska I, Połomski P. Stress and the level of perceived anxiety among mariners: the mediating role of marital satisfaction. Int Marit Health 2013; 64: 221-225.

20. Siek S. Wybrane metody badania osobowości. Akademia Teologii Katolickiej, Warszawa 1993.

21. Plopa M. Więzi w małżeństwie i rodzinie. Metody badań. Oficyna Wydawnicza Impuls, Kraków 2005.

22. Marks SR, Huston TL, Johnson EM, MacDermid SM. Role balance among white married couples. J Mariage Family 2001; 63: 1083-1098.

23. Jeżewska M, Leszczyńska I, Grubman-Nowak M. Personality and temperamental features vs quality of life of Polish seafarers. Int Marit Health 2013; 64: 101-155. 